\title{
Civil Wars, from Beginning ... to End?
}

\section{Citation}

Armitage, David. 2015. "Civil Wars, from Beginning ... to End?" The American Historical Review 120 (5) (December): 1829-1837. doi:10.1093/ahr/120.5.1829.

\section{Published Version}

doi:10.1093/ahr/120.5.1829

\section{Permanent link}

http://nrs.harvard.edu/urn-3:HUL.InstRepos:29425100

\section{Terms of Use}

This article was downloaded from Harvard University's DASH repository, and is made available under the terms and conditions applicable to Open Access Policy Articles, as set forth at http:// nrs.harvard.edu/urn-3:HUL.InstRepos:dash.current.terms-of-use\#OAP

\section{Share Your Story}

The Harvard community has made this article openly available.

Please share how this access benefits you. Submit a story.

\section{Accessibility}




\section{Civil Wars, from Beginning ... to End? ${ }^{\dagger}$}

\section{DAVID ARMITAGE}

FROM THE ANCIENT WORLD TO OUR OWN TIMES, there has been near-universal agreement on two features of civil wars: that of all wars, they are the worst, and that they are so terrible because they seem interminable. Civil strife may not be an eternal fact of life - "the primary form of all collective conflict" - as some have claimed. ${ }^{1}$ However, for two thousand years, commentators have found civil war to be the most wrenching form of war, not least because it appears to be the most difficult to end. The primal Roman poet of civil war, Lucan, wrote in the opening lines of his Bellum civile (60-65 C.E.), "no foreign sword has ever penetrated / so: it is wounds inflicted by the hand of fellow-citizens that have sunk deep"; later in his poem, a bereaved parent laments: "These sufferings await, again to be endured, this will be the sequence / of the warfare, this will be the outcome fixed for civil strife."2 Almost four centuries later, Augustine narrated Rome's history in his City of God (413-426 C.E.) as a series of civil wars that were "more bitter than all [Rome's] foreign wars," in which "a chain of causes linked one crime with another." ${ }^{3}$ Fast-forward to the late twentieth century, and we find former French president Charles de Gaulle expressing similar sentiments on a trip to Spain in 1970: "All wars are bad, because they symbolize the breakdown of politics itself. But civil wars, in which there are brothers in both trenches, are unforgivable, because peace is not born when the war

† Forthcoming, American Historical Review, 120, no. 5 (December 2015).

${ }^{1}$ Hans Magnus Enzensberger, Civil Wars: From L.A. to Bosnia, trans. Piers Spence and Martin Chalmers (New York, 1994; original German ed. 1993), quote from 11; Russell Jacoby, Bloodlust: On the Roots of Violence from Cain and Abel to the Present (New York, 2011).

${ }^{2}$ Lucan, Bellum civile (I, 31-32; II, 223-224), in Lucan, Civil War, trans. Susan H. Braund (Oxford, 1992), 3-4, 27.

${ }^{3}$ Augustine, The City of God against the Pagans, ed. and trans. R. W. Dyson (Cambridge, 1998), 138 (II. 30). 
concludes." ${ }^{4}$ Because civil wars are so peculiarly agonizing and leave such deep scars on historical memory, they appear to be almost as hard to end as they are awful to endure. "If war is hell," the historian Arno Mayer proposed in 2000, with a nod to William Tecumseh Sherman, "then civil war belongs to hell's deepest and most infernal regions." ${ }^{5}$

Ending civil war is the starting point for each of the essays in this timely $A H R$ Roundtable, published to coincide with the sesquicentennial of the formal conclusion of the U.S. Civil War in 1865. They span the whole history of civil war, from ancient Rome to the present, and over every inhabited continent, from the Americas and Africa to Europe and Asia. They examine the varied conditions and methods for concluding civil wars, from military victory and constitutional settlement to amnesties, peace agreements, and international treaties. They also movingly describe the anguished aftermaths of civil war: among them, burying the dead, physical reconstruction, the dislocation of refugees, and the traumas of memory. Each engages with the rich historiography on specific civil wars and many draw upon the work of contemporary political scientists who have analyzed civil war termination synoptically and synthetically. ${ }^{6}$ Taken together, they constitute the most extensive comparative treatment of civil war-and not just of ending civil war-ever assembled. ${ }^{7}$

${ }^{4}$ Quoted in Gregorio Marañon Moya, "El general De Gaulle, en Toledo," El País, August 8, 1981, 8: "Todas las guerras son malas, porque simbolizan el fracaso de toda política. Pero las guerras civiles, en las que en ambas trincheras hay hermanos, son imperdonables, porque la paz no nace cuando la guerra termina."

${ }^{5}$ Arno J. Mayer, The Furies: Violence and Terror in the French and Russian Revolutions (Princeton, N.J., 2000), 323.

${ }^{6}$ Roy Licklider, ed., Stopping the Killing: How Civil Wars End (New York, 1995); Charles King, Ending Civil Wars, Adelphi Paper 308 (Oxford, 1997); Barbara F. Walter, Committing to Peace: The Successful Settlement of Civil Wars (Princeton, N.J., 2002); Monica Duffy Toft, Securing the Peace: The Durable Settlement of Civil Wars (Princeton, N.J., 2010). For a succinct recent survey of this literature, see Joakim Kreutz, "How Civil Wars End (and Recur)," in Edward Newman and Karl DeRouen, Jr., eds., Routledge Handbook of Civil Wars (London, 2014), 349-362.

${ }^{7}$ For similar compilations on civil war, though mostly with less temporal depth and spatial scope, see Jean-Clément Martin, ed., La guerre civile: Entre histoire et mémoire (Nantes, 1994); Gabriele Ranzato, ed., Guerre fratricide: Le guerre civili in 
Three features mark this roundtable as unique: its scope, its comparisons, and its lessons The first is simply the range of historical examples covered here. For the most part, serial analysis of war termination in general, and of civil war termination in particular, has been conducted on a relatively narrow timescale of two centuries at most. Social scientists who study civil war have generally relied on large collections of data such as the Uppsala Conflict Data Program's Armed Conflict Dataset, which begins in 1946, or the Correlates of War Project at the University of Michigan, whose baseline is $1816 .{ }^{8}$ Yet any truly historical study of civil war-its genealogy, its morphology, its durability, or its terminability-must stretch ten times further than the horizon of these analyses. As Josiah Osgood notes, the Romans invented the term "civil war" (bellum civile) in the first century B.C.E. ${ }^{9}$ At least within the Western tradition, the Romans also have a strong claim to have invented civil war itself, as a phenomenon distinct from tumult, sedition, and the other less formalized episodes of internal violence the Greeks had called stasis. ${ }^{10}$ In this regard, the instances gathered here are salutary in treating civil wars and their termination over a longue durée of twenty-two centuries, from their beginnings in

età contemporanea (Turin, 1994); Peter Waldmann and Fernando Reinares, eds., Sociedades en guerra civil: Conflictos violentos de Europa y América Latina (Barcelona, 1999); Jordi Canal, ed., Las guerras civiles en la España contemporánea (Madrid, 2004); Sabina Ferhadbegović and Brigitte Weiffen, eds., Bürgerkriege erzählen: Zum Verlauf unziviler Konflikte (Konstanz, 2011); Jordi Canal and Eduardo González Calleja, eds., Guerras civiles: Una clave para entender la Europa de los siglos XIX y XX (Madrid, 2012). For other comparative studies on narrower time scales, see, for example, Philip B. Minehan, Civil War and World War in Europe: Spain, Yugoslavia, and Greece, 1936-1949 (New York, 2006); Stanley G. Payne, Civil War in Europe, 1905-1949 (Cambridge, 2011).

8 UCDP/PRIO Armed Conflict Dataset, Uppsala Conflict Data Program, http://www.pcr.uu.se/research/UCDP/; Meredith Reid Sarkees and Frank Whelon Wayman, Resort to War: A Data Guide to Inter-State, Extra-State, Intra-State, and Non-State Wars, 1816-2007 (Washington, D.C., 2010).

${ }^{9}$ Josiah Osgood, "Ending Civil War at Rome: Rhetoric and Reality, 88 B.C.E.-197 C.E.," this issue; see also Osgood, Caesar's Legacy: Civil War and the Emergence of the Roman Empire (Cambridge, 2006).

10 David Armitage, Civil War: A History in Ideas (New York, 2016), chap. 1, "Inventing Civil War: The Roman Tradition." Giorgio Agamben, Stasis: La guerra civile come paradigma politico (Turin, 2015), and Ninon Grangé, Oublier la guerre civile? Stasis, chronique d'une disparition (Paris, 2015), offer an opposing view. 
republican Rome to future prospects in South Asia, unlike conventional studies that have dealt solely with intrastate conflicts since the Second World War. ${ }^{11}$

Greater temporal depth allows for more enlightening comparisons among civil wars and their endings: the second impressive quality of this roundtable as a whole. The obvious analogy here is with the history of revolutions-those other transformative, often violent, political processes that have appeared sequentially across time and up to the present. ${ }^{12}$ Historians have generally preferred to study civil wars, like revolutions, individually and have left the cumulative analysis of both civil wars and revolutions to social scientists. Our tendency is toward profligacythe reconstruction of contextual specificity through the interpretation of often intractable original sources-while our colleagues in adjacent social sciences prefer parsimony: "the reduction of potentially incommensurate phenomena to uniform categories," as David A. Bell has recently described their procedure for analyzing revolutions. ${ }^{13}$ This division of labor has generated multiple historical case studies of particular civil wars; it has also served to reaffirm a methodological nationalism in their study that historians have begun to repudiate in favor of international, transnational, and global approaches to their subjects. The cumulative and collaborative approach adopted here may help to encourage more comparative consideration of civil wars, transnationally and transtemporally.

The roundtable consists mostly of treatments of specific national instances of civil war-among them Roman, French, English, Chinese, Syrian, American, Spanish, El Salvadorean, Liberian, and Afghan. Their juxtaposition shows that comparative examination of civil wars can adopt the serialism of the social sciences without losing the contextualism prized by historians. Unlike the study of revolutions, which

\footnotetext{
${ }^{11}$ For example, Stephen John Stedman, Donald Rothchild, and Elizabeth M. Cousens, eds., Ending Civil Wars: The Implementation of Peace Agreements (Boulder, Colo., 2002); Matthew Preston, Ending Civil War: Rhodesia and Lebanon in Perspective (London, 2004); Shanna Kirschner, Trust and Fear in Civil Wars: Ending Intrastate Conflict (Lanham, Md., 2015).

12 David Armitage, "Every Great Revolution Is a Civil War," in Keith Michael Baker and Dan Edelstein, eds., Scripting Revolution: A Historical Approach to the Comparative Study of Revolutions (Palo Alto, Calif., 2015), 57-68.

13 David A. Bell, “Afterword,” ibid., 345-353, here 347.
} 
has a long pedigree stretching from the mid-seventeenth century to the present, the transtemporal and transnational comparison of civil wars is still in its infancy. By exemplifying what Tobie Meyer-Fong here calls "the plausibility and desirability of dialogue among historians working in different geographical areas and time periods" on civil war, this roundtable marks a promising start to an ambitious area of historical inquiry. ${ }^{14}$ By encouraging comparisons across space and time, such an effort can provide more robust answers to the problems long posed by civil war in the past, as well as better questions for understanding how to end it in the future.

Comparative history shows that what might be learned from many civil wars is proportionately greater than the lessons to be drawn from any particular instance: the roundtable's third main collective contribution. ${ }^{15}$ By offering multiple examples of civil war, taken from widely differing times and places, under a broad range of political regimes (premodern and modern, monarchical and republican, imperial and statist, absolutist and democratic), and with a great variety of outcomes, the essays here provide a spectrum of the possibilities for ending civil war, from "giving war a chance" (the method of military victory) through to various forms of negotiated settlement, power-sharing, and internationally enforced agreements. ${ }^{16}$ The Romans experimented variously with dictatorship, proscription, spectacle (in the form of triumphs), the manipulation of memory, and ultimately dynasticism as successive, if not always successful, prophylactics against the curse of civil war, and many of their remedies were imitated in the wake of later civil wars. For example, Allan Tulchin suggests that absolute monarchy "inhibited compromise" during the French Wars of Religion, but that its capacities-notably shows of force, the manipulation of munificence, and the negotiation of religious

14 Tobie Meyer-Fong, "Where the War Ended: Violence, Community, and Commemoration in China's Nineteenth-Century Civil War," this issue.

15 Though for a salutary caution about comparison, see Stathis N. Kalyvas, "How not to Compare Civil Wars: Greece and Spain," in Martin Baumeister and Stefanie Schüler-Springorum, eds., "If You Tolerate This ...": The Spanish Civil War in the Age of Total War (Frankfurt, 2008), 247-263.

16 Edward N. Luttwak, "Give War a Chance," Foreign Affairs 78, no. 4 (July/August 1999): 36-44; Monica Duffy Toft, "Ending Civil Wars: A Case for Rebel Victory?," International Security 34, no. 4 (Spring 2010): 7-36. 
tolerance-ultimately helped to bring decades of conflict to a close. ${ }^{17}$ The restoration of monarchy in England after 1660, when joined with confessional compromise, likewise brought peace, Matthew Neufeld argues, but only in tandem with the amnesia of an Act of Pardon, Indemnity and Oblivion (1660), a strategy whose origins go back to Athens in the fifth century B.C.E. ${ }^{18}$ By contrast, the reassertion of dynasticism, along with documentary destruction and "physical and ideological reconstruction," lent only temporary closure after the Taiping War, as Meyer-Fong shows. ${ }^{19}$ Like other mid-nineteenth-century conflicts, in Syria and the United States, that civil war left much unfinished business and lingering questions after its formal termination-what one Spanish historian has called in a later context a "long uncivil peace" (larga paz incivil). ${ }^{20}$

Such indeterminacy foreshadowed the twentieth-century traumas of civil war. For example, Sandie Holguín shows that in Spain the Francisco Franco regime deliberately "prolonged its civil war" to maintain power until 1975; this was followed after Franco's death by a deliberate "Pact of Forgetting" (Pacto de Olvido) among Spanish politicians of all stripes. ${ }^{21}$ Clean closure also eluded peacemakers in sub-Saharan Africa and will likely not come for Afghanistan. Competing narratives of civil war-whether as "liberation wars" or "criminal wars"-have determined colliding remedies for conflict in the one, according to William Reno, while the

17 Allan A. Tulchin, "Ending the French Wars of Religion," this issue.

18 Matthew Neufeld, "From Peacemaking to Peacebuilding: The Multiple Endings of England's Long Civil Wars," this issue; Neufeld, The Civil Wars after 1660: Public Remembering in Late Stuart England (Woodbridge, 2013). On the Athenian amnesty, see, for example, Nicole Loraux, The Divided City: On Memory and Forgetting in Ancient Athens, trans. Corinne Pache with Jeff Fort (New York, 2002; original French ed. 1997); Andrew Wolpert, Remembering Defeat: Civil War and Civic Memory in Ancient Athens (Baltimore, 2002).

${ }^{19}$ Meyer-Fong, "Where the War Ended." See also Tobie Meyer-Fong, What Remains: Coming to Terms with Civil War in 19th Century China (Stanford, Calif., 2013).

20 Julián Casanova, "Presentación," in Casanova (coord.), Francisco Espinosa Maestre, Conxita Mir, and Francisco Moreno Gómez, Morir, matar, sobrevir: La violencia en la dictadura de Franco (Barcelona, 2002), ix-xi, here $\mathrm{x}$, quoted in Sandie Holguín, "How Did the Spanish Civil War End? ... Not So Well," this issue.

${ }^{21}$ Holguín, "How Did the Spanish Civil War End?"; Paloma Aguilar, Memory and Amnesia: The Role of the Spanish Civil War in the Transition to Democracy, trans. Mark Oakley (New York, 2002; original Spanish ed. 1996). 
unintended consequences of outside intervention will continue to affect the other, if Abdulkader Sinno is correct. ${ }^{22}$ Reno's illuminating emphasis on narrative highlights the ways in which scholarship itself can now influence how civil war ends, as the literature on, for example, "greed and grievance" in causing civil war generates narratives that shape the responses of human rights groups, tribunals, and international organs such as the World Bank. ${ }^{23}$ These narratives can also inspire or deter outside intervention into existing conflicts. Historical examples do not always point in a single direction: in this sense, Sinno is surely right to conclude his examination of intervention in Afghanistan with a caution that "the lessons of history need not be deterministic." ${ }^{24}$ The more lessons that can be learned, the greater the chances of avoiding past mistakes in ending future civil conflicts: for, as Reno reminds us, "Ideas turn out to be very important in shaping how a civil war ends." 25

Civil wars can feel bitterly invasive to those who go through them because of their divisiveness, their apparent resistance to regulation, their tendency to inspire vengeance, and the very intimacy of their violence. As a result, they often leave lingering hostility, historical trauma, and fractious memory in their wake. Most of the essays in the roundtable treat wars that dragged on, flared up, or mutated into other forms of slow, deep violence long after any formal settlement or surrender. Rome's five Roman civil wars stretched over nearly three hundred years. The eight civil wars that later came to be called the French "Wars of Religion" lasted from 1562 to 1598 and were indeed ended by the re-imposition of monarchy. Seventeenth-century Britain suffered three civil wars over nine years (1642-1651),

\footnotetext{
22 William Reno, "Lost in Transitions: Civil War Termination in Sub-Saharan Africa," this issue; Abdulkader Sinno, "Partisan Intervention and the Transformation of Afghanistan's Civil War," this issue.

23 See especially Paul Collier and Anke Hoeffler, "Greed and Grievance in Civil War," Oxford Economic Papers 56, no. 4 (October 2004): 563-595.

24 Sinno, "Partisan Intervention and the Transformation of Afghanistan's Civil War." 25 Reno, "Lost in Transitions."
} 
along with a fourth that never was, the Glorious Revolution of $1688-1689 .{ }^{26}$ The Taiping War lasted thirteen years (1851-1864) and was the nineteenth century's bloodiest. The U.S. Civil War carried on formally for only four years (1861-1865), but by some accounts was not concluded until five years beyond Appomattox in 1870, as Republicans declared that "wartime continued" through Reconstruction, anticipating the increasing elasticity of "wartime" more generally in the twentieth century. ${ }^{27}$ The civil war in El Salvador went on for twelve years, while present-day Afghanistan threatens to suffer fresh "conflict that is curiously similar to the preCoalition civil war" when (or if) the U.S.-led forces in the country finally depart. These experiences of long duration, difficult termination, and bitterly contested memory could have been illustrated equally well by other drawn-out civil wars, in Guatemala (1960-1996), Lebanon (1975-1990), and Sri Lanka (1983-2009), for instance. ${ }^{28}$

Social scientists who study civil wars have queried whether they are objectively harsher, more destructive, or more lacking in logic than other kinds of conflict. ${ }^{29}$ In the process, they have confirmed that civil wars seem particularly agonizing because they do last longer and are yet more likely to recur than other

${ }^{26}$ J. G. A. Pocock, "The Fourth English Civil War: Dissolution, Desertion and Alternative Histories in the Glorious Revolution," Government and Opposition 23, no. 2 (April 1988): 151-166.

27 Paul A. Cimbala and Randall M. Miller, eds., The Great Task Remaining before Us: Reconstruction as America's Continuing Civil War (New York, 2010); Mark Grimsley, "Wars for the American South: The First and Second Reconstructions Considered as Insurgencies," Civil War History 58, no. 1 (March 2012): 6-36; Elizabeth R. Varon, Appomattox: Victory, Defeat, and Freedom at the End of the Civil War (New York, 2014); Gregory P. Downs, After Appomattox: Military Occupation and the Ends of War (Cambridge, Mass., 2015). On the broader extension of "wartime," see Mary L. Dudziak, War Time: An Idea, Its History, Its Consequences (New York, 2012).

${ }^{28}$ Kirsten Weld, Paper Cadavers: The Archives of Dictatorship in Guatemala (Durham, N.C., 2014); Robert Fisk, Pity the Nation: Lebanon at War (London, 1990); Samanth Subramanian, This Divided Island: Stories from the Sri Lankan Civil War (London, 2015).

${ }^{29}$ Stathis N. Kalyvas, The Logic of Violence in Civil War (Cambridge, 2006); Stathis N. Kalyvas, Ian Shapiro, and Tarek Masoud, eds., Order, Conflict, and Violence (Cambridge, 2008). 
wars. It now appears that "the most likely legacy of a civil war is further civil war."30 In our own century, most of these apparently "neverending wars" have been resumptions of earlier civil wars. ${ }^{31}$ These recent discoveries about civil war recurrence are re-discoveries of what observers have known for centuries, even millennia, about civil war: its endlessness and its endurance. The Romans had learned that civil wars were like volcanoes: both destructive and dormant, shatteringly violent and yet disturbing when quiescent because they were likely to erupt again at any time. ${ }^{32}$ To stir the suppressed memory of civil war was, in the chilling words of the poet Horace, to "tread on fire / smouldering under ashes."33 Pace the orator and historian Titus Labienus, forgetting (oblivio) was not the best defense against civil war, although, as Osgood remarks, half-forgetting it may have been. ${ }^{34}$ That was hardly an option for Rome's heirs in the Latin West and beyond. Until well into the nineteenth century, Roman conceptions shaped perceptions of civil war in the Western world and its imperial offshoots, though they were overlaid with multiple historical memories and intersected with other conceptions of internal conflict in Arabic, Asian, and other traditions. ${ }^{35}$ Roman accounts of serial civil war-by Appian, Augustine, Caesar, Florus, Lucan, Plutarch, and Tacitus, among

30 Paul Collier, Anke Hoeffler, and Måns Söderbom, "On the Duration of Civil War," Journal of Peace Research 41, no. 3 (May 2004): 253-273; James D. Fearon, "Why Do Some Civil Wars Last So Much Longer Than Others?," ibid., 275-301; Barbara F. Walter, "Does Conflict Beget Conflict? Explaining Recurring Civil War," ibid., 371388; Paul Collier, Wars, Guns, and Votes: Democracy in Dangerous Places (New York, 2009), quote from 139.

${ }^{31}$ Ann Hironaka, Neverending Wars: The International Community, Weak States, and the Perpetuation of Civil War (Cambridge, Mass., 2005); The World Bank, World Development Report 2011: Conflict, Security, and Development (Washington, D.C., 2011), 57.

32 On the Roman understanding of civil war recurrence, see Brian W. Breed, Cynthia Damon, and Andreola Rossi, "Introduction," in Breed, Damon, and Rossi, eds., Citizens of Discord: Rome and Its Civil Wars (Oxford, 2010), 3-22, here 10-12.

33 Horace, Odes 2.1, in Horace, The Complete Odes and Epodes, trans. David West (Oxford, 1997), 56.

34 "Optima civilis belli defensio oblivio est": Seneca, Controversiae 10.3.5, quoted in Alain M. Gowing, Empire and Memory: The Representation of the Roman Republic in Imperial Culture (Cambridge, 2005), 82; Osgood, "Ending Civil War at Rome."

35 Armitage, Civil War. 
others-gave evidence that the remedies for civil war could be double-edged in their effects. The imposition, or re-imposition, of monarchy might in some circumstances be a cure, but struggles over the succession could equally likely engulf "the world in blood and ashes," as the anti-monarchical republican Thomas Paine charged in $1776 .{ }^{36}$ History supplied cumulative repertoires for their conclusion as well as warnings about their potential interminability, but ultimately every civil war thus had to find its own ending.

How civil wars end is intimately linked to how they begin and the conditions under which they are fought. As Ussama Makdisi shows, the 1860 civil war in the empire paralleled near-contemporaneous events in the United States in presenting in each case the "quintessentially nineteenth-century problem of shifting from a system of overt discrimination to one that emphasized non-discrimination and notionally equal citizenship". ${ }^{37}$ In the two cases, that transformation was framed in different but not, Makdisi suggests, incommensurable terms: religious in Ottoman Syria, racial in the case of the United States. The outcomes were also distinct: Union victory in North America cemented sovereign territoriality along with the reassertion of racial dominance; Ottoman authority over a pacified Syria was diluted in Mount Lebanon by religious "coexistence in a diminished Ottoman sovereignty."38 By contrast, the pacification of the American South extended the war well beyond the moment of formal surrender, though it was not accompanied by trials of the defeated or reprisals against them. This was a tempered use of force designed to snuff out once and for all the avant-garde nationalist aspirations of southerners for

\footnotetext{
${ }^{36}$ Thomas Paine, Common Sense (1776), in Paine, Collected Writings, ed. Eric Foner (New York, 1995), 5-59, here 19.

${ }^{37}$ Ussama Makdisi, "Diminished Sovereignty and the Impossibility of 'Civil War' in the Modern Middle East." See also Leila Tarazi Fawaz, An Occasion for War: Civil Conflict in Lebanon and Damascus in 1860 (Berkeley, Calif., 1994); Ussama Makdisi, The Culture of Sectarianism: Community, History, and Violence in Nineteenth-Century Ottoman Lebanon (Berkeley, Calif., 2000).

${ }^{38}$ Makdisi, "Diminished Sovereignty and the Impossibility of 'Civil War' in the Modern Middle East."
} 
self-determination. ${ }^{39}$ As William Blair argues, the use of force retarded reconciliation, while "questions concerning citizenship and rights" for African Americans remained unresolved for almost a century. ${ }^{40}$ This was hardly what the reformist French politician Agénor de Gasparin envisaged in 1865 to be "the liberal conclusion of a civil war." 41

Concluding civil wars became paradoxically more complex and more likely over the course of the nineteenth and twentieth centuries as they came increasingly to be matters of international concern. From the time of the Roman civil wars until the second half of the eighteenth century, such conflicts remained mostly internal or domestic matters. The American and French revolutions and the movements for redistributing sovereignty and authority in early-nineteenth-century southern Europe and Spanish America brought questions of international recognition and intervention to the forefront of political and legal calculations for the first time. ${ }^{42}$ In the following two centuries, during the Spanish Civil War and especially in the Cold War, outside powers became more inclined to use the parties in civil wars as proxies or to attempt to broker peace settlements through international institutions. Joaquin M. Chávez demonstrates that the civil war in El Salvador ended more conclusively in 1992 not only because the contending sides had been more evenly matched, but because international actors, including the United Nations, the United States, and the Soviet Union, had a greater stake in the war's termination. This may not have been enough to create "the basis for a more peaceful and just society in El

${ }^{39}$ On Confederate nationalism as a species of contemporary self-determination, see especially Don H. Doyle, The Cause of All Nations: An International History of the American Civil War (New York, 2014), 27-29.

40 Blair, "Finding the Ending of America's Civil War"; see also William A. Blair, With Malice toward Some: Treason and Loyalty in the Civil War Era (Chapel Hill, N.C., 2014).

${ }^{41}$ Agénor de Gasparin to William H. Seward, May 1, 1865, quoted in Blair, "Finding the Ending of America's Civil War."; Doyle, The Cause of All Nations, 132-138.

42 For recent histories of early interventionism, see Gary J. Bass, Freedom's Battle: The Origins of Humanitarian Intervention (New York, 2008); Brendan Simms and D. J. B. Trim, eds., Humanitarian Intervention: A History (Cambridge, 2011); Stefano Recchia and Jennifer M. Welsh, eds., Just and Unjust Military Intervention: European Thinkers from Vitoria to Mill (Cambridge, 2013). 
Salvador," but it did help to end the war decisively. ${ }^{43}$ The likelihood of civil wars being terminated by international agreements will surely only increase, even as the dangers of what Reno calls "direct partisan intervention" in civil wars have also grown. ${ }^{44}$

Sometimes generations must pass before the fires of civil war can be extinguished. As Neufeld notes in the conclusion to his essay, "in the case of seventeenth-century England, it took fifty years, three legislative settlements, one revolution, and one foreign war to achieve civil peace once and for all." 45 Even that chastening summation may overlook the aftershocks of the British—rather than just English-civil wars, in Scotland (where the Jacobite threat lingered until 1745, if not longer) and especially in Ireland, where, as Lord Macaulay wrote in the 1840s, the historian's "steps-to borrow a fine image used on a similar occasion by a Roman poet-are on the thin crust of ashes beneath which the lava is still glowing." 46 Similarly, the historical memory of the Taiping War would be argued over well beyond the end of the Qing Dynasty against which the leaders of the Taiping Heavenly Kingdom Revolutionary Movement had raised their banners: indeed, it would only be after the Chinese Revolution in 1911 that the events could be branded as a civil war-rather than as an anti-dynastic "rebellion"-at all. This parallels the aftermath of the contemporary conflict in the United States, which official documents, such as the seventy-volume official history of the U.S. "Civil War" published between 1880 and 1891, called "the War of the Rebellion," a title clearly intended to delegitimate the cause of the defeated Confederate "rebels." ${ }^{27}$ Recent arguments over the flying of the Confederate battle flag in South Carolina, Alabama, and Mississippi suggest that even 150 years later, the embers of conflict in the

\footnotetext{
43 Joaquín M. Chávez, "How Did the Civil War in El Salvador End?"

${ }^{44}$ Sinno, "Partisan Intervention and the Transformation of Afghanistan's Civil War."

${ }^{45}$ Neufeld, "From Peacemaking to Peacebuilding."

${ }^{46}$ Thomas Babington Macaulay, The History of England from the Accession of James the Second, 4th ed., 6 vols. (London, 1849), 2: 125.

47 U.S. Department of War, The War of the Rebellion: A Compilation of the Official Records of the Union and Confederate Armies, 70 vols. (Washington, D.C., 18801891).
} 
United States have not entirely cooled. ${ }^{48}$ Likewise, the fiercely contested status of Yasukuni Shrine in Tokyo (originally constructed in 1869 as a memorial to the imperial loyalists who died during Japan's Boshin War) and of the Valle de los Caídos in Spain (a monument to the Nationalist dead of the Spanish Civil War and the burial place of Francisco Franco) keeps the divisions of long-terminated conflicts alive into the present. ${ }^{49} \mathrm{In}$ all these cases, to forgive civil war has not been to forget it.

This AHR Roundtable raises as many questions as it answers about the terminability, or interminability, of civil war. In light of two thousand years' experience of ceaseless, repeated civil wars, its theme may appear to embody something of a question mal posée. Asking whether civil wars end rather than how they end might better capture the uncertainties of the lingering hostility, historical trauma, and fractious memory they often leave in their wake. This matters especially because in the twenty-first-century world, almost all wars are now "civil" wars: according to one widely cited estimate, there have been 259 armed conflicts since 1945, and more than 95 percent of those recorded since 1989 were intra-state, not inter-state, conflicts. The great majority of those became "internationalized civil wars," with the participation of near-neighbors or other external agents: in 2014, thirty-nine of the forty active conflicts globally were of this kind, in Afghanistan, Mali, Somalia, and elsewhere. ${ }^{50}$ As one analyst has recently noted, "There is uncertainty as to how to define victory and defeat in these circumstances or even

48 Robert E. Bonner, Colors and Blood: Flag Passions of the Confederate South (Princeton, N.J., 2002); David W. Blight, Race and Reunion: The Civil War in American Memory (Cambridge, Mass., 2003); David W. Blight, American Oracle: The Civil War in the Civil Rights Era (Cambridge, Mass., 2013).

${ }^{49}$ Akiko Takenaka, Yasukuni Shrine: History, Memory, and Japan's Unending Postwar (Honolulu, 2015); Tàrio Rubio, El Valle de los Caídos y la represión franquista (Tarragona, 2011).

50 Therése Pettersson and Peter Wallensteen, "Armed Conflicts, 1946-2014," Journal of Peace Research 52, no. 4 (July 2015): 536-550; Kristian Skrede Gleditsch, "Transnational Dimensions of Civil War," Journal of Peace Research 44, no. 3 (May 2007): 293-309; Jeffrey T. Checkel, ed., Transnational Dynamics of Civil War (Cambridge, 2013). 
when such conflicts meaningfully begin and end."51 Civil wars have produced not just destruction and dislocation within their respective countries, but escalating numbers of refugees: 500,000 during the Spanish Civil War, almost 1 million from El Salvador in the 1980s, and over 4 million and counting from Syria since 2012.52 The essays in this roundtable demonstrate that, in cases of civil war, "committing to peace" might not be a straightforward means of "securing the peace". ${ }^{53}$ Civil war is a long-lived phenomenon. Ongoing civil wars, from Afghanistan to Syria, seem intractable. Their consequences can shape regions and histories for generations. Despite "the better angels of our nature," we still have far to go before "winning the war" on civil war. 54

David Armitage is the Lloyd C. Blankfein Professor of History and Chair of the Department of History at Harvard University. He is the author of Civil War: A History in Ideas, forthcoming from Alfred A. Knopf in the fall of 2016. Among his fourteen other books are, most recently, Foundations of Modern International Thought (Cambridge University Press, 2013), The History Manifesto, co-authored with Jo Guldi (Cambridge University Press, 2014), and Pacific Histories: Ocean, Land, People, co-edited with Alison Bashford (Palgrave Macmillan, 2014). He is now completing an edition of John Locke's colonial writings for Oxford University Press and co-editing collections on the law of nations in global context (with Jennifer Pitts, also for Oxford University Press) and on the cultural history of peace in the Enlightenment (with Stella Ghervas, for Bloomsbury Academic).

\footnotetext{
${ }^{51}$ Michael Clarke, "The Ending of Wars and the Ending of Eras," RUSI Journal 160, no. 4 (August/September 2015): 4-9, here 4.

${ }^{52}$ As of November 3, 2015, the UNHCR had registered 4,290,332 Syrian refugees; Syria Regional Refugee Response, Inter-Agency Information Sharing Portal, Regional Overview, http://data.unhcr.org/syrianrefugees/regional.php.

${ }^{53}$ Walter, Committing to Peace; Toft, Securing the Peace.

${ }^{54}$ Steven Pinker, The Better Angels of Our Nature: Why Violence Has Declined (New York, 2011); Joshua S. Goldstein, Winning the War on War: The Decline of Armed Conflict Worldwide (New York, 2011).
} 